\title{
Conscious Self-Regulation and Self-organization of Life During the COVID-19 Pandemic
}

\author{
Yury P. Zinchenko ${ }^{\mathrm{a}}$, Varvara I. Morosanova ${ }^{\mathrm{b}^{*}}$, \\ Nailia G. Kondratyuk ${ }^{b}$, Tatiana G. Fomina ${ }^{b}$ \\ ${ }^{a}$ Faculty of Psychology, Lomonosov Moscow State University, Moscow, Russia \\ ${ }^{\mathrm{b}}$ Psychological Institute of the Russian Academy of Education, Moscow, Russia \\ * Corresponding author. E-mail: morosanova@mail.ru
}

Background. In a pandemic situation, the search for psychological resources for successful self-organization of life under the changing conditions becomes an urgent issue. Revealing the role of a person's conscious activity to achieve such selforganization during the lockdown period is the goal of this study.

Objective. Our main task was to monitor self-assessments of life self-organization in different age groups. Another was to evaluate the extent to which conscious self-regulation contributes to the success of self-organization, to overcoming its difficulties, and to accepting the uncertainty of the future.

Design. The data were obtained online on the Testograf platform (www.testograf.ru), which was provided by the all-Russian research project "Exploring at home!" (www.issleduemdoma.ru), a study which ran from late April to early June 2020. The sample was comprised of 1634 people, ages 18-60, from 69 regions of Russia. The methods were "Morosanova's Self-regulation Profile Questionnaire SRPQM 2020" and the authors' ad hoc questionnaire "Self-organization of life during a lockdown."

Results. The majority of respondents assessed their level of self-organization as medium (67.6\%) and high (17.3\%). The general level of self-regulation was associated with successful self-organization in all age groups. Regression analysis revealed that being able to cope with and accept uncertainty depended primarily on flexibility, persistence, planning goals, and modeling conditions. Overcoming the difficulties of self-organization depended on the same indicators, with additional contributions of reliability and programming of actions. Students demonstrated significantly lower levels of self-regulation than older people; as a result, young people experienced more difficulties in organizing their lives under self-isolation conditions.

Conclusion. The higher the level of conscious self-regulation, the more productive a person is when self-organizing his/her behavior in case of a lockdown. The difficulties of self-organization, in turn, are associated with a low level of regulatory resources.

Keywords: coronavirus; COVID-19; conscious selfregulation; selforganization; age 


\section{Introduction}

The pandemic situation in which the world has found itself in 2020 is unprecedented in its scale and power of influence on all domains of human life (Brooks et al., 2020; Usher, Durkin, \& Bhullar, 2020). In these crisis conditions, medical resources are of primary importance for saving lives. At the same time, a heavy demand for psychological resources has emerged, as required for preventing problems, enhancing immunity, and facilitating people's rehabilitation from the disease. The lack of psychological resources is among the main causes of suffering from the deaths of close associates, job loss, restrictions on people's mobility, complications of family relationships linked to isolation, and the uncertainty and fear for the future (Guterres, 2020). In this situation, a person's ability to consciously self-regulate requires additional research. In the broadest sense, self-regulation is an important human capability, one that contributes to success and well-being in a broad variety of spheres (Baumeister \& Alquist, 2009).

We consider conscious self-regulation from the standpoint of V. Morosanova. She defines it as the human ability to consciously set goals and manage their achievement by means of functional regulatory-cognitive processes (i.e., goal planning, modeling of significant conditions, programming of actions, and results evaluation), and instrumental regulatory-personal features (i.e., flexibility, independence, and reliability) (Morosanova, 2010). Through applying these regulatory resources, a person coordinates his/her other psychological resources to advance and achieve the goals of his/her activity (Morosanova, 2014).

A person's general ability for self-regulation determines the success of his/her behavior, especially in the case of significant changes in living conditions, the emergence of new tasks, and the need to master unfamiliar or unusual types of activity (Konopkin, 2011; Morosanova \& Bondarenko, 2016). The current period of the COVID-19 pandemic represents just such a significant change, and is characterized by a significant increase in the level of uncertainty in all areas of life, including work, leisure, food, and sports (Stankovska, Memedi, \& Dimitrovski, 2020; Wang, Di, Ye, \& Wei, 2020).

The crisis conditions of the pandemic and the introduction of quarantine restrictions have dramatically changed people's educational and work environment. In all areas of education and professional training, the emphasis has had to shift to remote digital technologies, which drastically change and, in essence, narrow the scope of personal interaction in educational practice. According to researchers, $25 \%$ to $28 \%$ of students under these conditions show an increased level of worry and anxiety, which in turn reduces their productivity (Cao et al., 2020; Wang et al., 2020). It is quite natural that the burden on conscious self-regulation is increasing. Its resource value for education, professional self-determination, and in general, for work and life in a situation of global risks and large-scale changes of the human existence, is difficult to overestimate.

It can be assumed that conscious self-regulation makes a significant contribution to the self-organization of life under the new conditions of the coronavirus pandemic.

Self-organization was previously often considered with regard to various aspects of educational activity: the formation of skills of rational behavior in the edu- 
cational process; organization of independent work for students; formation and improvement of self-learning activities; self-development; and personality selfrealization (e.g., Ishkov, 2016; Kostromina, 2010). The concept of "self-organization" is also conceptually related to the phenomena of time structuring (SobolKwapińska et al., 2018), time management (Oettingen, Kappes, Guttenberg, \& Gollwitzer, 2015), procrastination (Steel, 2007; Van Eerde \& Klingsieck, 2018), and time control (Bond \& Feather, 1988).

In our opinion, the success of self-organization during a lockdown period is primarily manifested in making lifestyle changes based on accepting the need for quarantine measures during the pandemic spread. In this regard, we hypothesize that conscious self-regulation can predict success in life self-organization under the changing conditions, and in overcoming the difficulties associated with uncertainty of the future.

This empirical study was carried out during the quarantine period in order to find answers to the following relevant questions:

1. Is there a relationship between a person's conscious self-regulation and his/ her self-organization under conditions of imposed isolation?

2. Which components of conscious self-regulation are associated with effective self-organization, overcoming the difficulties of self-isolation, and coping with the uncertainty of the future?

3. Are there any age differences in the components of conscious self-regulation and indicators of a person's self-organizations during a lockdown?

\section{Methods}

\section{Participants}

The study participants were recruited among the visitors to the website $w w w$. issleduemdoma.ru. They were invited to fill out the questionnaires in exchange for feedback. The study involved 1634 people (1386 female, $84.8 \%$ ), ages 18 to 60 $(\mathrm{M}=30.17, \mathrm{SD}=11.83)$. The sample came from 69 subjects (political divisions) of the Russian Federation. Online informed consent was obtained from the participants for processing their personal data strictly for scientific research purposes. Data quality assurance included removing outliers through the boxplot function.

\section{Procedure}

The survey was conducted from late April to early June 2020, starting three weeks after the introduction of the quarantine measures and self-isolation regime in the Russian Federation. The study was organized by means of the Russian service for online surveys Testograf ( $w w w . t e s t o g r a f . r u)$ as part of the all-Russian scientific project "Explore at home!" (www.issleduemdoma.ru).

\section{Questionnaires}

1. The 28-item Morosanova's Self-Regulation Profile Questionnaire (SRPQM), modified release of 2020, is designed to assess the general ability for conscious self-regulation and its components, which are consistently manifested in various types of 
the voluntary activity and life situations (Morosanova \& Kondratyuk, 2020). The questionnaire includes seven scales: four of them assess regulatory-cognitive processes (goal planning; modeling of significant conditions; programming of actions; and results evaluation) and three of them evaluate regulatory-personal features (flexibility; reliability; and insistency). The questionnaire also contains the cumulative indicator of the seven scales, and make up the general level of self-regulation. Participants responded to each item on a 5-point Likert scale, which ranged from $1=$ "strongly disagree" to 5 = "strongly agree," so that the total score for each scale ranged from 4 to 20 , and for the cumulative scale, from 28 to 140 . Cronbach's alphas for the scales in the present study ranged from 0.60 to 0.83 .

The goal planning scale characterizes individual differences in setting the goals of activities (e.g., "I plan my future goals down to the details"). The modeling of significant conditions scale evaluates a person's understanding of external and internal significant conditions for achieving his/her activity goals ("It is difficult for me to take into account the changing circumstances in time"). The programming of actions scale defines individual characteristics of a person's conscious construction of his/her action program ("To carry out the work, I need to plan the sequence of my actions"). The results evaluation scale evaluates the adequacy of a subject's assessment of him or herself, his/her actions, and the results of his/her activities and behavior ("At the end of the day, I summarize what has been done").

The flexibility scale measures the level of regulatory flexibility as the ability to rebuild, and to adjust the self-regulation system with regard to changing external and internal conditions for activity ("I can easily adapt to new situations"). The reliability scale reflects the stability of conscious self-regulation of a person's mental and practical activity in complicated, psychologically stressful situations ("It is usually difficult for me to work when I am upset"). The insistency scale allows the diagnosis of perseverance and determination in achieving the goals of activities ("I persist in solving a difficult task"). And the integrative scale (general level of self-regulation) shows the overall level of an individual's system of behavior selfregulation or, in other words, the regulatory resources of a person for achieving his goals.

2. For the purposes of the present study, the authors designed an ad hoc questionnaire called "Self-organization of life during a lockdown." The questionnaire consists of 16 points and includes three scales: 1) success in life self-organization; 2) difficulties in life self-organization; and 3) difficulties in accepting uncertainty. The general index of self-organization is calculated by summing up the scores from all three scales. It's worth noting that when calculating the general index of selforganization, the items included in the scales "difficulties in life self-organization" and "difficulties in accepting uncertainty" are considered as inverse.

Participants were invited to answer a series of questions concerning their self-organization during the lockdown period, using a 5-point Likert scale from 1 ("strongly disagree") to 5 ("strongly agree"). The total score for scale 1 (success in life self-organization) ranged from 8 to 40 ; for scale 2 (difficulties in life selforganization) and 3 (difficulties in accepting uncertainty), from 4 to 20, and for the "general index of self-organization," from 16 to 80 .

The scale "success in life self-organization" reveals how successfully adults cope with the need to work, study, and communicate remotely under conditions of self- 
isolation, and whether they manage to adapt and organize their lives under the new circumstances: i.e., to observe a daily routine, maintain working hours and rest. The scale "difficulties in life self-organization" reflects the emerging concerns and difficulties around the new way of life, including its organization, compliance with lockdown rules, remote work, study, and communication. The scale "difficulties in accepting uncertainty" is related to the acceptability and attitude toward the situation of uncertainty arising from the coronavirus pandemic spreading in the world. The "general index of self-organization" characterizes the overall personal effectiveness of life self-organization under the conditions of a lockdown and global pandemic.

In order to confirm the relevance of the questionnaire structure, we conducted an exploratory factor analysis (analysis of the main components by Varimax rotation method with Kaiser Normalization). From the 16 statements, we have extracted three factors corresponding to the three scales of the questionnaire. Together, the three factors, with a total of 16 items, explained $56.92 \%$ of the variance. The first factor, with an eigenvalue of 2.57 , explained $28.60 \%$ of variance. The second factor, with an eigenvalue of 1.53 , explained $16.97 \%$ of the variance. And the third factor, with an eigenvalue of 1.02 , explained $11.35 \%$ of the variance. The three factors underlying the three scales were well-defined, having mostly large loadings. The scales' internal consistency ranged from 0.67 to 0.81 .

\section{Data Analysis}

Data analysis was performed using the Statistical Package for Social Sciences (SPSS) (version 26). Pearson's correlation analyses were conducted to explore the correlations between conscious self-regulation and variables of life self-organization. A one-way ANOVA was used to indicate significant differences in the selfregulation and self-organization variables among the age groups.

The sample was split into three age groups. The first group consisted of subjects ages $18-25$ years ( 827 people, $84 \%$ female). Most of them were the students involved in remote educational activities during the lockdown period. The second group included respondents ages $26-40$ years ( 433 people, $84 \%$ female). The third group consisted of subjects ages $41-60$ years (374 people, $86 \%$ female). A linear regression analysis was conducted to investigate how conscious self-regulation related to people's self-organization during a lockdown.

\section{Results}

Table 1 shows the means, standard deviations, and min and max values for selfregulation and self-organization components in our sample. Based on descriptive statistics, we analyzed the percentage of respondents with low, medium, and high levels of the general index of life self-organization during lockdown. The study results show that $15.1 \%$ of respondents $(\mathrm{N}=246)$ experienced difficulties in accepting the need to comply with lockdown rules, and in organizing a new mode of life based on remote work/study and communication. Sixty-seven, six tenths percent $(67.6 \%)$ of respondents $(\mathrm{N}=1104)$ had an average level of efficiency in their life self-organization during the lockdown. High individual effectiveness in organizing one's life in this situation was observed in $17.3 \%(\mathrm{~N}=284)$. 
Table 1

Descriptive Statistics $(N=1634)$

\begin{tabular}{lcccc}
\hline Variables & Min & Max & Mean & SD \\
\hline Goal planning & 4 & 20 & 12.30 & 3.46 \\
Programming of actions & 4 & 20 & 14.69 & 2.80 \\
Modeling of significant conditions & 4 & 20 & 12.59 & 2.78 \\
Results evaluation & 4 & 20 & 12.35 & 3.58 \\
Flexibility & 4 & 20 & 12.92 & 3.16 \\
Reliability & 4 & 20 & 10.18 & 3.31 \\
Insistency & 4 & 20 & 14.18 & 3.00 \\
General level of self-regulation & 43 & 136 & 89.24 & 13.34 \\
Success in life self-organization & 8 & 40 & 24.92 & 6.69 \\
Difficulties in life self-organization & 4 & 20 & 11.88 & 3,66 \\
Difficulties in accepting uncertainty & 4 & 20 & 12.22 & 3.62 \\
General index of self-organization & 16 & 80 & 48.81 & 10.93 \\
\hline
\end{tabular}

A correlation analysis was carried out to identify significant relationships between self-regulation components and the special demands of life self-organization during lockdown (see Table 2).

Table 2

Results of the correlation analysis between variables of self-regulation and self-organization

\begin{tabular}{lcccc}
\hline \multicolumn{1}{c}{ Self-regulation } & \multicolumn{4}{c}{ Self-organization } \\
\cline { 2 - 5 } & $\begin{array}{c}\text { Success } \\
\text { in life self- } \\
\text { organization }\end{array}$ & $\begin{array}{c}\text { Difficulties } \\
\text { in life self- } \\
\text { organization }\end{array}$ & $\begin{array}{c}\text { Difficulties } \\
\text { in accepting } \\
\text { uncertainty }\end{array}$ & $\begin{array}{c}\text { General } \\
\text { index of self- } \\
\text { organization }\end{array}$ \\
\hline Goal planning & $0.21^{* *}$ & $-0.13^{* *}$ & $-0.20^{* *}$ & $0.24^{* *}$ \\
Programming of actions & $0.17^{* *}$ & $-0.06^{*}$ & -0.01 & $0.12^{* *}$ \\
Modeling of significant condi- & $0.24^{* *}$ & $-0.23^{* *}$ & $-0.26^{* *}$ & $0.31^{* *}$ \\
tions & $0.20^{* *}$ & $-0.07^{* *}$ & $-0.11^{* *}$ & $0.18^{* *}$ \\
Results evaluation & $0.39^{* *}$ & $-0.20^{* *}$ & $-0.29^{* *}$ & $0.39^{* *}$ \\
Flexibility & $0.14^{* *}$ & $-0.22^{* *}$ & $-0.28^{* *}$ & $0.25^{*}$ \\
Reliability & $0.33^{* *}$ & $-0.09^{* *}$ & $-0.08^{* *}$ & $0.26^{* *}$ \\
Insistency & $0.40^{* *}$ & $-0.24^{* *}$ & $-0.29^{* *}$ & $0.42^{* *}$ \\
General level of self-regulation & & & & \\
\hline
\end{tabular}

Note. ${ }^{\star} p<0.05 ;{ }^{* *} p<0.01$. 
The results indicated a large number of statistically significant correlations. Positive relationships were recorded between the regulatory components, scale of success in life self-organization and the general index of self-organization. That is, the higher the level of self-regulation, the easier a person could change his/ her lifestyle and organize his/her behavior (activity) during a lockdown period. Negative correlations were obtained with respect to the scales reflecting the difficulties of self-organization and acceptance of uncertainty. This result indicates that people with a reduced level of conscious self-regulation are more likely to experience various difficulties in self-organization under the changed conditions. It is more difficult for them to observe the lockdown rules, maintain optimal productivity levels in educational and professional activities, and adapt to the situation of uncertainty.

A regression analysis made it possible to examine the specifics of regulatory predictors of people's self-organization during a lockdown. Four regression models were analyzed for all manifestations of self-organization, including the general index. Seven self-regulation components served as the independent variables. The dependent variables were indicators of self-organization. The tolerance and VIF (Variance Inflation Factor) were acceptable for all variables (1.18-1.50); therefore the regression models are acceptable for further interpretation. Table 3 shows the final regression models that include only significant predictors (see Table 3).

Table 3

Results of the regression analysis

\begin{tabular}{|c|c|c|c|c|c|}
\hline Criterion & Adjusted $\mathrm{R}^{2}$ & F/df & $\begin{array}{l}\text { Significant } \\
\text { predictor }\end{array}$ & Beta & $\mathbf{p}$ \\
\hline \multirow{5}{*}{$\begin{array}{l}\text { Success in life } \\
\text { self-organization }\end{array}$} & \multirow[t]{5}{*}{0.21} & \multirow[t]{5}{*}{$63.81(7), 1626$} & Flexibility & 0.30 & 0.00 \\
\hline & & & Insistency & 0.15 & 0.00 \\
\hline & & & Results evaluation & 0.07 & 0.00 \\
\hline & & & Programming & 0.07 & 0.00 \\
\hline & & & Reliability & 0.05 & 0.04 \\
\hline \multirow{4}{*}{$\begin{array}{l}\text { Difficulties in life } \\
\text { self-organization }\end{array}$} & \multirow[t]{4}{*}{0.09} & \multirow[t]{4}{*}{$25.29(7), 1626$} & Flexibility & -0.15 & 0.00 \\
\hline & & & Reliability & -0.16 & 0.00 \\
\hline & & & Modeling & -0.13 & 0.00 \\
\hline & & & Insistency & 0.06 & 0.04 \\
\hline \multirow{5}{*}{$\begin{array}{l}\text { Difficulties in } \\
\text { accepting uncertainty }\end{array}$} & \multirow[t]{5}{*}{0.16} & \multirow[t]{5}{*}{$45.92(7), 1626$} & Flexibility & -0.21 & 0.00 \\
\hline & & & Reliability & -0.20 & 0.00 \\
\hline & & & Goal planning & -0.13 & 0.00 \\
\hline & & & Modeling & -0.12 & 0.00 \\
\hline & & & Insistency & 0.10 & 0.00 \\
\hline \multirow{4}{*}{$\begin{array}{l}\text { General index } \\
\text { of self-organization }\end{array}$} & \multirow[t]{4}{*}{0.23} & \multirow[t]{4}{*}{$71.48(7), 1626$} & Flexibility & 0.31 & 0.00 \\
\hline & & & Reliability & -0.15 & 0.00 \\
\hline & & & Modeling & 0.11 & 0.00 \\
\hline & & & Goal planning & 0.07 & 0.01 \\
\hline
\end{tabular}


It should be noted that composition of the regulatory predictors differed for various indicators of self-organization. At the same time, regulatory flexibility turned out to be significant for all indicators of self-organization. This regulatorypersonal characteristic was associated with the ability to quickly restructure one's behavior and activities under changing external and internal conditions, which, of course, is essential during a lockdown period. A reduced level of this ability, apparently, leads to difficulties in self-organization and performance in situations of uncertainty.

The regulatory-personal characteristic of reliability also acted as a significant predictor of the ability to self-organize. This feature characterizes the stability of the self-regulation system in psychologically stressful situations. A high level of reliability indicates that a person is able to effectively organize his activities, while maintaining its optimal results, despite obvious situational difficulties.

Interesting results were identified for the regulatory-personal characteristic of insistency, which reflects persistence in achieving goals. This is the only regulatory component positively associated with difficulties in self-organization and accepting uncertainty. Apparently, for persistent and determined people, the lockdown situation turned out to be a serious obstacle for achieving their goals. Limited opportunities and a sense of impotence led to aggravation of the perception of uncertainty and awareness of the complexity of the situation.

The regulatory-cognitive components also proved to be significant predictors of self-organization. Conscious programming of actions and evaluation of their results were significant predictors of success in life self-organization during the lockdown time. Apparently, reflection on their actions and their results in the new conditions allowed people to quickly adapt and adjust their behavior, redistributing their capabilities. Programming of actions under conditions of a lockdown is also a valuable resource, since the lack of clear time limits in the remote mode of learning and working activities can cause the illusion of expandable deadlines. People with a high level of programming their actions more successfully organized themselves to effectively perform their duties on schedule in a lockdown situation.

Yet another significant predictor for the general index of self-organization was the goal planning process. This process has significance in building an entire system of conscious self-regulation of activity, which, as a whole, contributes to the effective organization of a person's new lifestyle.

Our study revealed that the difficulties of self-organization were associated with the insufficiently developed capabilities for modeling and programming processes. Difficulties in accepting uncertainty were higher in people with the reduced cognitive-regulatory processes of modeling and planning.

Thus, the regression analysis made it possible to identify the specific regulatory resources that are significant for self-organization of life during a lockdown period. The foremost resources were the regulatory-personal features of flexibility and reliability. High levels of the cognitive-regulatory processes of planning, modeling, programming, and results evaluation also contributed to productive self-organization.

At the next stage of the data analysis, we identified the age-related differences in the manifestations of self-regulation and self-organization. Analysis of the frequency of occurrence of high, low, and medium levels of self-organization efficiency (according to the general index of life self-organization) within different age 
groups revealed that among the young people (the first group), the percentage of respondents with a low general index of self-organization was higher (18\%) than in the two other groups (12\% in each group). Table 4 shows the results of the variance analysis by ANOVA.

Table 4

Means and standard deviations in different age groups for variables of self-regulation and self-organization and comparisons for observed means

\begin{tabular}{|c|c|c|c|c|c|c|c|c|}
\hline \multirow{3}{*}{ Variables } & \multicolumn{6}{|c|}{ Age groups } & \multirow{3}{*}{ F/df } & \multirow{3}{*}{$\begin{array}{c}\text { Sign. diff. } \\
\text { between } \\
\text { groups }\end{array}$} \\
\hline & \multicolumn{2}{|c|}{$\begin{array}{c}\text { Group 1 } \\
18-25(\mathrm{~N}=827)\end{array}$} & \multicolumn{2}{|c|}{$\begin{array}{c}\text { Group 2 } \\
26-40(N=433)\end{array}$} & \multicolumn{2}{|c|}{$\begin{array}{c}\text { Group 3 } \\
41-60(N=374)\end{array}$} & & \\
\hline & M & SD & $\mathbf{M}$ & SD & M & SD & & \\
\hline Goal planning & 11.98 & 3.43 & 12.77 & 3.53 & 12.47 & 3.38 & $7.95(2)$ & 0.00 \\
\hline Programming & 14.29 & 2.92 & 15.08 & 2.75 & 15.15 & 2.45 & $18.16(2)$ & 0.00 \\
\hline Modeling & 12.45 & 2.73 & 12.81 & 2.85 & 12.68 & 2.83 & $2.59(2)$ & 0.07 \\
\hline Results evaluation & 12.24 & 3.54 & 12.41 & 3.62 & 12.56 & 3.63 & $1.09(2)$ & 0.33 \\
\hline Flexibility & 12.94 & 3.21 & 13.38 & 3.00 & 12.37 & 3.17 & $10.29(2)$ & 0.00 \\
\hline Reliability & 9.57 & 3.30 & 10.83 & 3.31 & 10.81 & 3.11 & $30.01(2)$ & 0.00 \\
\hline Insistency & 13.87 & 3.16 & 14.60 & 2.88 & 14.38 & 2.71 & $9.47(2)$ & 0.00 \\
\hline $\begin{array}{l}\text { General level } \\
\text { of self-regulation }\end{array}$ & 87.34 & 12.82 & 91.88 & 13.60 & 90.42 & 13.58 & $18.64(2)$ & 0.00 \\
\hline $\begin{array}{l}\text { Success in life } \\
\text { self-organization }\end{array}$ & 24.46 & 6.98 & 25.19 & 6.40 & 25.64 & 6.34 & $4.46(2)$ & 0.01 \\
\hline $\begin{array}{l}\text { Difficulties in life } \\
\text { self-organization }\end{array}$ & 12.34 & 3.70 & 11.28 & 3.60 & 11.59 & 3.52 & $13.79(2)$ & 0.00 \\
\hline $\begin{array}{l}\text { Difficulties in } \\
\text { accepting uncertainty }\end{array}$ & 12.37 & 3.69 & 12.00 & 3.63 & 12.19 & 3.44 & $1.50(2)$ & 0.22 \\
\hline $\begin{array}{l}\text { General index } \\
\text { of self-organization }\end{array}$ & 47.76 & 11.12 & 49.91 & 10.77 & 49.87 & 10.52 & $7.85(2)$ & 0.00 \\
\hline
\end{tabular}

The pairwise comparisons were used to indicate differences between the three groups (Bonferroni post hoc testing). The results demonstrated that indices of conscious self-regulation and the general index of self-organization under selfisolation conditions were significantly lower in the first age group. Significant differences were obtained between this group and groups 2 and 3 for the variables of programming, reliability, insistency, general level of self-regulation, and all the indicators of self-organization. The results demonstrated that resources of conscious self-regulation and the general index of self-organization in a lockdown time are significantly lower in the first age group. Young people experience difficulties in their life self-organization, apparently due to the fact that productive patterns of conscious self-regulation only start to actively form in this age period under the influence of the requirements of educational and professional activities. 
The results in the second and third groups are generally similar. Significant differences between them were revealed only in terms of regulatory flexibility. It might be assumed that older people would find it more difficult to rebuild, abandon their usual lifestyle, and adapt to the new conditions, but these difficulties were compensated for by a higher general level of the conscious self-regulation.

Next, we analyzed the specifics of significant regulatory predictors of the general index of self-organization in the three selected age groups. Regression analysis showed some differences, both in the composition of predictors and in the percentage of variance explained. In the first group, significant predictors were planning $(\beta=0.08, \mathrm{p}<.05)$, modeling $(\beta=0.10, \mathrm{p}<.01)$, flexibility $(\beta=0.39, \mathrm{p}<.001)$, and reliability $(\beta=0.15, p<.001)$. In the second group, they were modeling $(\beta=0.16$, $\mathrm{p}<.01)$, flexibility $(\beta=0.23, \mathrm{p}<.001)$, and reliability $(\beta=0.14, \mathrm{p}<.01)$. In the third group they were flexibility $(\beta=0.27, \mathrm{p}<.001)$, reliability $(\beta=0.14, \mathrm{p}<.01)$, and insistency $(\beta=0.13, \mathrm{p}<.05)$. The percentage of explained variance $\mathrm{R} 2$ is greatest for the first group -0.27 .

These results indicate the importance of self-regulation for for youth being able to self-organize their lives. For older people, who, as a rule, have had some professional experience, self-organization is provided to a certain extent by the automated regulatory skills. Our results emphasize the importance of development and self-development of conscious self-regulation for effective self-organization under lockdown conditions.

\section{Discussion}

The pandemic situation has led to significant changes in the mode of implementing professional and educational activities. People's perception of discrepancies and the inadequacy of the new requirements triggers the processes of conscious selfregulation of human activities (Kooij, 2020). For most people, remote work and education have turned out to be a new form of life. It has previously been shown that long-term remote work in online environment can significantly reduce employees' self-esteem and self-confidence due to an emerging sense of professional and social isolation (Golden, Veiga, \& Dino, 2008). At the same time, the present study showed that a significant percentage of Russian respondents (85\%) assessed their self-organization as successful, which, however, does not exclude having difficulties.

Among the main problems with remote work/education, as indicated by Jaiswal and Arun, are, first of all, violations of schedule, then an increase/decrease of work time, and thus the inability to find a balance between work (or school) and family (personal) affairs. All this inevitably affects the level of productivity (Jaiswal \& Arun, 2020).

In the model developed in this study, in addition to the indicator of "difficulties of self-organization," we also included indicators of "difficulties of accepting uncertainty" and "success of self-organization," which made our analysis more specific and comprehensive.

The study results allowed us to uncover the significant contribution of the capability for conscious self-regulation in people's life self-organization under condi- 
tions of imposed self-isolation. Our data are consistent with the previous studies which demonstrated that people with a high general level of conscious self-regulation are most successful in atypical and new situations (Konopkin, 2004; Morosanova, 2014). It is worth pointing out that high self-regulation is more pronounced when performing atypical and new tasks (Morosanova \& Bondarenko, 2016) and serves as a significant resource for overcoming difficult life situations (Aspinwall \& Taylor, 1997) and acute stress (Morosanova, Kondratyuk, Gaidamashko, \& Voytikova, 2018).

Previously, in a sample of people in high-risk professions, we have shown that regulatory flexibility, modeling, and reliability serve as special predictors of the ability to cope with stress in emergencies (Morosanova, Kondratyuk, \& Gaidamashko, 2020; Morosanova et al, 2018). The present study results are consistent with those results: flexibility and reliability, as well as modeling and goal planning, turned out to be the foremost predictors of the general self-organization index in the situation of imposed isolation. These findings also contribute to Smith and her colleagues' conclusion that inflexibility and intolerance of uncertainty, combined with high levels of social isolation, lead to increasing depression and, in particular, anxiety (Smith, Gavey, Riddell, Kontari, \& Victor, 2020).

Psychological flexibility and the ability to stay in the present moment and participate in the value-oriented activities, even in the presence of negative emotions in a pandemic situation, turned out to be a positive factor. It has been shown that components such as behavioral awareness and openness to new experiences were associated with lower levels of distress (Kroska, Roche, Adamowicz, \& Stegall, 2020). A study conducted on a British sample during the lockdown in May 2020 demonstrated that psychological flexibility explained 5 to $18 \%$ of the variance of distress (including that specific to COVID-19) and psychological well-being (Dawson \& Golijani-Moghaddam, 2020).

Regulatory-cognitive processes of planning goals, modeling significant conditions, programming actions, and evaluating results also made a positive contribution to self-organization and, as a result, success in task performance. In turn, the difficulties of self-organization were associated with the low level of these regulatory processes, which becomes especially obvious under conditions of imposed selfisolation. New interesting results were obtained concerning the contribution of the regulatory-personal feature of insistency to the success of self-organization. Due to their ambiguity, these results require further research.

Analysis of the age specifics of self-organization and self-regulation carried out on the large sample of the Russian respondents from various territories made it possible to establish that young people (mostly students) experienced more difficulties in organizing their learning activities in remote mode, compared with older participants. Young people were also characterized by lower levels of conscious self-regulation.

In a recent study, Inan, Yukselturk, Kurucay, and Flores (2017) emphasized that self-regulation processes, and primarily planning, are important factors explaining success and subjective satisfaction of students in the process of online learning. Dabbagh and Kitsantas also noted that self-regulation is becoming a critical factor 
for success in digital learning, as students must rely more on their self-regulation resources for learning activities (Dabbagh \& Kitsantas, 2004). Our data confirmed and developed these ideas.

As for older people, our results demonstrated that their more developed system of conscious self-regulation (compared to the young participants), allowed them to organize their activities more productively, despite the fact that, as a rule, these people have to not only regulate their professional activities, but also cope with household and family affairs.

Our findings support previous studies showing that older workers are better at regulating emotions (Scheibe, Spieler, \& Kuba, 2016). This, in turn, is necessary for effective adaptation and response to career challenges under pandemic conditions (Restubog, Ocampo, \& Wang, 2020). Therefore, in some countries, researchers record a negative relationship between age and stress in self-isolation situations (Losada-Baltar et al., 2020). In addition, it has been shown that older people use various self-regulation strategies aimed at constantly maintaining the necessary level of compliance with the requirements of their environment (Kooij, 2020).

\section{Conclusion}

In a pandemic, conscious self-regulation is of particular importance for overcoming uncertainty in all spheres of human activity and for people's successful life selforganization. From our point of view, self-organization under conditions of selfisolation is characterized by a rational change in lifestyle due to the need to comply with the rules of quarantine measures.

This study demonstrated that the higher the conscious self-regulation level, the more productive a person is in self-organization of his/her behavior in a lockdown period. Analysis of the results identified specific regulatory peculiarities that help coping with the difficulties of self-organization; foremost were regulatory reliability and flexibility. The study results as a whole can become the basis for developing practical recommendations for self-organization of educational and professional activities during a pandemic.

\section{Limitations}

The study participants represented various territories of the Russian Federation which implemented different restrictive modes during the COVID-19 pandemic, based on local morbidity levels. We plan in the future to consider the contribution of the residence region factor in the identified patterns. For future research, it also seems relevant to consider the personality determinants in the self-regulation and self-organization of people who have to work and study distantly in the lockdown conditions. These features may explain the existence of patterns of increased vs. reduced productivity in remote mode among different people.

We found no gender differences in self-regulation and self-organization. Note that this result is not unexpected, given that the universal structure of conscious self-regulation does not imply any gender-based differences, since its development is determined primarily by personality characteristics. It is likely that this conclu- 
sion is also true in relation to the self-organization phenomenon, but this aspect has yet to be investigated.

It seems promising that we have already begun research into the role of selfregulation resources and actual self-organization in the prevention of negative stressful conditions during a pandemic. The pandemic situation increases stress and leads to negative emotional reactions, which, in turn, reduce immunity and lead to an increase in morbidity (Bulgakova, 2011; Vetlugina et al., 2012). Thus it would seem that conscious self-regulation can serve as a psychological resource for stabilizing and enhancing immunity, since a high level of self-regulation, according to our data, impedes the development of acute stress reactions and negative emotional states in emergency situations (Morosanova, 2010; Morosanova et al., 2018). Verification of this assumption requires organization of special interdisciplinary research in the future.

\section{References}

Aspinwall, L.G., \& Taylor, S.E. (1997). A stitch in time: Self-regulation and proactive coping. Psychological Bulletin, 121(3), 417-436. https://doi.org/10.1037/0033-2909.121.3.417

Baumeister, R.F., \& Alquist, J.I. (2009). Self-regulation as a limited resource strength model of control and depletion. In J.P. Forgas, R.F. Baumeister \& D.M. Tice (Eds.), Psychology of Self-regulation. Cognitive, affective, and motivational processes (pp. 21-33). New York, London: Psychology Press.

Bond, M.J., \& Feather, N.T. (1988). Some correlates of structure and purpose in the use of time. Journal of Personality and Social Psychology, 55(2), 321-329. https://doi.org/10.1037/0022-3514.55.2.321

Brooks, S.K., Webster, R.K., Smith, L.E., Woodland, L., Wessely, S., Greenberg, N., \& Rubin, G.J. (2020). The psychological impact of quarantine and how to reduce it: rapid review of the evidence. The Lancet, 395(10227), 912-920. https://doi.org/10.1016/S0140-6736(20)30460-8

Bulgakova, O.S. (2011). Immunitet i razlichnye stadii stressornogo vozdeystviia [Immunity and the various stages of stress effects]. Uspekhi sovremennogo yestestvoznaniia [Advances in current natural sciences], 4, 31-35.

Cao, W., Fang, Z., Hou, G., Han, M., Xu, X., Dong, J., \& Zheng, J. (2020). The psychological impact of the COVID-19 epidemic on college students in China. Psychiatry Research, 287 (112934). https:// doi.org/10.1016/j.psychres.2020.112934

Dabbagh, N., \& Kitsantas, A. (2004). Supporting self-regulation in student-centered web-based learning environments. International Journal on E-learning, 3(1), 40-47. Retrieved from https://www. learntechlib.org/primary/p/4104/

Dawson, D., \& Golijani-Moghaddam, N. (2020). COVID-19: Psychological flexibility, coping, mental health, and wellbeing in the UK during the pandemic. Journal of Contextual Behavioral Science, 17, 126-134. https://doi.org/10.1016/j.jcbs.2020.07.010.

Golden, T.D., Veiga, J.F., \& Dino, R.N. (2008). The impact of professional isolation on teleworker job performance and turnover intentions: Does time spent teleworking, interacting face-to-face, or having access to communication-enhancing technology matter? Journal of Applied Psychology, 93(6), 1412-1421. https://doi.org/10.1037/a0012722

Guterres, A. (2020). We Need to Take Action to Address the Mental Health Crisis in This Pandemic. United Nations Secretary-General. Retrieved from https://www.un.org/sg/en/content/sg/articles/2020-05-21/we-need-take-action-address-the-mental-health-crisis-pandemic

Inan, F., Yukselturk, E., Kurucay, M., \& Flores, R. (2017). The impact of self-regulation strategies on student success and satisfaction in an online course. International Journal on E-learning, 16(1), 23-32. Retrieved from https://www.learntechlib.org/primary/p/147296/

Ishkov, A.D. (2016). Psikhologicheskiye zakonomernosti i mekhanizmy lichnostnoy samoorganizatsii [Psychological regularities and mechanisms of personal self-organization]. Ekonomika $i$ predprinimatel'stvo [Journal of Economy and Entrepreneurship], 2(1), 655-659. 
Jaiswal, A., \& Arun, C.J. (2020). Unlocking the COVID-19 Lockdown: Work from Home and Its Impact on Employees. Preprint (Version 1) available at Research Square. https://doi.org/10.21203/ rs.3.rs-34556/v1

Konopkin, O.A. (2004). Obshchaya sposobnost' k samoregulyatsii kak faktor sub"ektnogo razvitiia [General ability for self-regulation as a factor of subjective development]. Voprosy psychologii [Issues in Psychology], 2, 128-135.

Konopkin, O.A. (2011). Psikhologicheskie mekhanizmy reguliatsii deiatel'nosti [Psychological mechanisms of activity regulation]. Moscow: LENAND.

Kooij, D.T. (2020). The Impact of the Covid-19 Pandemic on Older Workers: The Role of Self-Regulation and Organizations. Work, Aging and Retirement, 6(4), 233-237. https://doi.org/10.1093/ workar/waaa018

Kostromina, S.N. (2010). Strukturno-funktsional'naia model' samoorganizatsii deiatel'nosti [Structurally functional model of self-organization]. Vestnik Sankt-Peterburgskogo universiteta. Seria 12. Psychologiia. Sociologiia. Pedagogika [Vestnik of Saint-Petersburg University. Sociology], 4, 153-160.

Kroska E., Roche, A., Adamowicz, J., \& Stegall, M. (2020). Psychological flexibility in the context of COVID-19 adversity: Associations with distress. Journal of Contextual Behavioral Science, 18, 28-33. https://doi.org/10.1016/j.jcbs.2020.07.011.

Losada-Baltar, A., Jiménez-Gonzalo, L., Gallego-Alberto, L., Pedroso-Chaparro, M.D.S., FernandesPires, J., \& Márquez-González, M. (2020). "We’re staying at home." Association of self-perceptions of aging, personal and family resources and loneliness with psychological distress during the lock-down period of COVID-19. The Journals of Gerontology: Series B., 1-7. https://doi. org/10.1093/geronb/gbaa048

Morosanova, V.I. (2010). Conscious self-regulation of voluntary activity: Differential approach. Psychology in Russia: State of the Art, 3, 333-350. https://org.doi/10.11621/pir.2010.0017

Morosanova, V.I. (2014). Osoznannaia samoregulyatsiia proizvol'noi aktivnosti cheloveka kak psikhologicheskii resurs dostizheniia tselei [Conscious self-regulation of personal activity as a psychological resource for achieving goals]. Teoreticheskaia i eksperimentalnaia psikhologiia [Theoretical and Experimental Psychology], 7(4), 62-78.

Morosanova, V.I., \& Bondarenko, I.N. (2016). Obshchaia sposobnost' k samoreguliatsii: operatsionalizatsiia fenomena i eksperimental'nyi podkhod $\mathrm{k}$ diagnostike ee razvitiia [General capacity for self-regulation: operationalization of the phenomenon and an experimental approach to diagnosing its development]. Voprosy psychologii [Issues in Psychology], 2, 109-123.

Morosanova, V.I. \& Kondratyuk, N.G. (2020). Oprosnik V.I. Morosanovoy «Stil” samoregulyatsii povedeniia - SSPM 2020 [Morosanova's Self-regulation profile questionnaire - SRPQM 2020], Voprosy psychologii [Issues in Psychology], 4, 155-167.

Morosanova, V.I., Kondratyuk, N.G., \& Gaidamashko, I.V. (2020). Nadezhnost' osoznannoi samoregulyatsii kak resurs dostizheniia tseley v professiyakh vysokogo riska [Reliability of self-regulation as a resource for goal achievement in high-risk occupations]. Vestnik Moskovskogo Universiteta. Seriya 14. Psikhologiia [Moscow University Psychology Bulletin], 1, 77-95. https://doi:10.11621/ vsp.2020.01.05

Morosanova, V., Kondratyuk, N., Gaidamashko, I., \& Voytikova, M. (2018). Self-regulation and personality traits in overcoming acute and chronic stress. The European Proceedings of Social \& Behavioural Sciences EpSBS, 460-470. https://dx.doi.org/10.15405/epsbs.2018.11.02.51

Oettingen, G., Kappes, H.B., Guttenberg, K.B., \& Gollwitzer, P.M. (2015). Self-regulation of time management: Mental contrasting with implementation intentions. European Journal of Social Psychology, 45(2), 218-229. https://doi.org/10.1002/ejsp.2090

Restubog, S.L.D., Ocampo, A.C.G., \& Wang, L. (2020). Taking control amidst the chaos: Emotion regulation during the COVID-19 pandemic. Journal of Vocational Behavior, 119, 103440. https:// doi.org/10.1016/j.jvb.2020.103440

Scheibe, S., Spieler, I., \& Kuba, K. (2016). An older-age advantage? Emotion regulation and emotional experience after a day of work. Work, Aging and Retirement, 2(3), 307-320. https://doi. org/10.1093/workar/waw010 
Smith, K., Gavey, S., Riddell, N., Kontari, P., \& Victor, C. (2020). The association between loneliness, social isolation, and inflammation: A systematic review and meta-analysis. Neuroscience \& Biobehavioral Reviews, 112, 519-541, https://doi.org/10.1016/j.neubiorev.2020.02.002

Sobol-Kwapińska, M., Jankowski, T., Przepiorka, A., Oinyshi, I., Sorokowski, P., \& Zimbardo, P. (2018). What Is the Structure of Time? A Study on Time Perspective in the United States, Poland, and Nigeria. Frontiers in Psychology, 9, 2078. https://doi.org/10.3389/fpsyg.2018.02078

Stankovska, G., Memedi, I., \& Dimitrovski, D. (2020). Coronavirus COVID-19 disease, mental health, and psychosocial support. Society Register, 4(2), 33-48. https://doi.org/10.14746/sr.2020.4.2.03

Steel, P. (2007). The nature of procrastination: A meta-analytic and theoretical review of quintessential self-regulatory failure. Psychological Bulletin, 133(1), 65-94. https://doi.org/10.1037/00332909.133.1.65

Usher, K., Durkin, J., \& Bhullar, N. (2020). The COVID-19 pandemic and mental health impacts. International Journal of Mental Health Nursing, 29(3), 315-318. https://doi.org/10.1111/inm.12726

Van Eerde, W., \& Klingsieck, K. (2018). Overcoming procrastination? A meta-analysis of intervention studies. Educational Research Review, 25, 73-85. https://doi.org/10.1016/j.edurev.2018.09.002

Vetlugina, T.P., Nikitina, V.B., Nevidimova, T.I., Lobacheva, O.A., Batukhtina, E.I., Stoyanova, I.Ya., \& Semke, V.Ya. (2012). Sistema immuniteta i uroven' trevozhnosti pri adaptatsii cheloveka k novym usloviiam zhiznedeiatel'nosti [Immunity system and anxiety level in adaptation of the person to new conditions of vital activity]. Fundamental'nye issledovaniia [Fundamental research], 1(9), $17-21$.

Wang, Y., Di, Y., Ye, J., \& Wei, W. (2020). Study on the public psychological states and its related factors during the outbreak of coronavirus disease 2019 (COVID-19) in some regions of China. Psychology, Health \& Medicine. https://doi.org/10.1080/13548506.2020.1746817

Original manuscript received July 11, 2020

Revised manuscript accepted November 21, 2020

First published online December 30, 2020

To cite this article: Zinchenko, Yu.P., Morosanova, V.I., Kondratyuk, N.G., Fomina, T.G. (2020). Conscious Self-Regulation and Self-organization of Life during the COVID-19 Pandemic. Psychology in Russia: State of the Art, 13(4), 168-182. DOI: 10.11621/pir.2020.0411 